\title{
ZRANB3 Gene
}

National Cancer Institute

\section{Source}

National Cancer Institute. ZRANB3 Gene. NCI Thesaurus. Code C116085.

This gene is involved in both DNA damage response and DNA rewinding. 